\title{
Civil Disobedience: Concept and Practice
}

\author{
Zawiyah Mohd Zain ${ }^{1} \&$ Mohammad Agus Yusoff ${ }^{2}$ \\ ${ }^{1}$ School of Government, Universiti Utara Malaysia, Malaysia \\ ${ }^{2}$ School of History, Politics and Strategy, Universiti Kebangsaan Malaysia, Malaysia \\ Correspondence: Zawiyah Mohd Zain, School of Government, College of Law Government and International \\ Studies, Universiti Utara Malaysia, 06010 Sintok Kedah, Malaysia. Tel: 60-12-534-2416. E-mail: \\ zmzain@uum.edu.my
}

Received: May 15, 2017

Accepted: May 31, 2017 Online Published: July 25, 2017

doi:10.5539/ass.v13n8p129

URL: https://doi.org/10.5539/ass.v13n8p129

\begin{abstract}
The concept of civil disobedience was introduced by David Henry Thoreau in 1849 by what he experienced in the fight against slavery system in USA. The aims of this paper is to discuss the concept of civil disobedience and analyse its practice in Malaysia. This paper base on content analysis and interview. The analysis shows that first, there have several features to justify the acts of civil disobedience that happened in society. Second, in Malaysia, the concept of civil disobedience is something new. This is because in general, opposition is the term used to indicate resistance. The opposition only involves the struggle for political purposes, while the concept of civil disobedience include broader aspects involving the opposition parties, non-governmental organizations, civil society and activists to create public awareness for the fight against injustice in government. However, in practice, civil disobedience has been present in Malaysia since before independence. Therefore, this article takes a broader approach in analysing civil disobedience in Malaysia, with discussion focusing on historical aspects and current practice.
\end{abstract}

Keywords: Civil disobedience, non-governmental organizations, Malaysian politics

\section{Introduction}

The concept of civil disobedience was introduced by David Henry Thoreau in 1849 by what he experienced in the fight against slavery in USA. This concept was later popularized by Gandhi in India in 1966, which uses the term Satyagraha. Civil disobedience aims to bring changes to government policies and it has been in existence since the $18^{\text {th }}$ century. In developed countries such as United States of America (USA), the purpose of civil disobedience is to demand justice from the government.

In Malaysia, the concept of civil disobedience is something new. This is because opposition is the term used to indicate resistance. The opposition only involves the struggle for political purposes, while the concept of civil disobedience include broader aspects involve the opposition parties, non-governmental organizations (NGOs), civil society and community activists to create public awareness for the fight against injustice in government. However, in practice, civil disobedience has occurred in Malaysia since before independence. The purpose of this paper is to discuss the concept of civil disobedience and its practice in Malaysia from the era of Mahathir Mohamad until the reign of Najib Razak.

\section{Method}

The current study adapted a qualitative method with two types of data, whereby, in-depth interviews were employed in generating primary data from experienced and knowledgeable respondents about the subject that is being studied. The informants representative of the government political party which is UMNO, MIC and MCA, opposition party such as PKR, PAS and DAP, and non-governmental organizations (NGOs). On the other hand, earlier studies, journals and government department's documents provided secondary data.

\section{Civil Disobedience Concept}

In general, civil disobedience is a form of people dissent against the government or its officers, as there are certain things that they are not satisfied with. Civil disobedience is defined by Rawls (1971) as a public, nonviolent, thorough yet political act perverse to law commonly aiming at bringing about a change in the law or government policies. It is further urged by Rawls that initially civil disobedience is a political act that does not 
only focus on the majority who hold political powers, but it is also directed and rationalized by the political principle of justice. Further still, civil disobedience according to Rawls is a public act not only concerned about principles, but it is it is done in the public not concealed. To add to that, civil disobedience is nonviolent since it expresses disobedience to law but within the limits of the law even though it is at outer edge thereof. Interestingly, the law is broken, but loyalty to it is still withheld by the public who are aware and willing to accept its legal consequences.

Bedau (1991) defines civil disobedience as an act which is illegal, committed openly, non-violently, and conscientiously, within the framework of the rule of law and with the intention of frustrating or protesting against some laws, policies, or decisions of the government (or some of its officers) (p.51).

Quigley \& Bahmueller (1991, p. 629), defines civil disobedience as a deliberate, public, conscientious, and nonviolent act that breaks a law in which the person accepts responsibility and punishment. It is an act of nonviolent protest undertaken to alleviate some injustice, usually with an appeal to some higher principle or law. Based on this definition, the act considered as civil disobedience is first, the citizen must disobey the law, and most often the law that is being broken is considered unjust. Second, the citizen would have to deliberately and publicly disobey the law. The citizen must be acting to serve the common good, not the personal interest. Third, the citizen must act conscientiously, in that he or she has an honest belief that his or her actions are intended to correct a grave injustice. Finally, the act must be nonviolent and the citizen must be willing to accept the consequences of his or her action.

There are two types of civil disobedience as viewed by Quigley \& Bahmueller (1991); individual or moral disobedience and organized or social civil disobedience. Quigley \& Bahmueller further explicated that civil disobedience may take place through the internet as people put across their criticisms and discontents to the government or its officers through blogs or social media, with the main of pressurizing the government to change unfair laws and policies.

Smith (2004) stated that civil disobedience is a public, illegal and political protest carried out against state or policies. Acts of civil disobedience might be justified within a constitutional democracy. Justification here is understood as a moral or political justification - where civil disobedient citizens claim that they are morally or politically entitled to disobey the law.

According to Klang (2005), practitioners of civil disobedience tend to justify their actions by pointing to the fact that they are fighting a larger injustice and in this role, they have the right to break the law. Therefore, the disobedient citizens are doing what they believe to be morally right despite the fact their actions unfortunately come into conflict with the enforced rules. Sheldon $(2005$, p. 60$)$ in encyclopaedia of political thought defines civil disobedience as disobeying or breaking of law for moral, religious, or other reasons, either by an individual or an organized group.

Consequently, scholars are of the opinion that there exist a number of important features of civil disobedience; disobedience of the law, disobedience that takes place in public due dissatisfaction with the government measures, unmerited laws or policies, non-violence acts and this act must be conscientiously carried out, finally, people's willingness to accept the consequences of their actions.

\section{Discussion}

\subsection{Civil Disobedience in Malaysia}

Civil disobedience in Malaysian history is said to have begun before independence when the Malays rose against the Malayan Union introduced by the British in Malaya (Malaysia) in 1946. The Malays looked at the Malayan Union as a British ploy to do away with the rights of the Malays as well as abolishing the Malay Sultanate. Consequently, after independence numerous civil disobedience actions cropped up due to the society's dissatisfaction with government attitude particularly on political and civil rights. Fortunately enough, it did not blast until 1998, a year considered to the advent of reform movement sparked off by the dismissal of the former Deputy Prime Minister Anwar Ibrahim, immediately after his imprisonment, hence, civil disobedience became rampant resulting from that incident, so, since then, civil disobedience became the custom through which people express their dissatisfaction with the government.

\subsubsection{Mahathir's Era}

Mahathir Mohammad's leadership as a Prime Minister of Malaysia started on July 1981. At the beginning of his tenure Mahathir had a strong urge of making fundamental changes thus; he introduced more positive policies and programs in his administration and politics. A good example was his liberal attitude towards political prisoners exhibited in the liberation of 21 political detainees under the Internal Security Act (ISA) in August 1981. As if 
that was enough, the administrative atmosphere also changed, emphasizing on the quality of public services, with a strong determination to combat corruption, improve bureaucratic efficiency and curtail political disputes at the federal and state levels.

Unfortunately, the second phase of Mahathir's leadership witnessed the emergence of a multiplicity of setbacks which resulted into objections from the community. This can be seen during 1984 to 1989, when civil disobedience related to development and environment appeared involving the Chinese community in Bukit Papan Perak, sparked off by government's decision to permit the construction of a radioactive waste site near Chinese residential areas by the Asian Rare Earth (ARE). This resulted into the arrest of several protestors in 1984 to 1987, something, that drew the attention of thousands to of people to take part including the Democratic Action Party (DAP) and Perak Anti Radioactive Committee (PARC) (Brown, 2004).

In addition to that, a public outcry arose in 1986 due to the government's amendment to the Official Secrets Act (OSA) when the issue of BMF corruption was made public through the Far Eastern Economic Review and the Asian Wall Street Journal (AWSJ). AWSJ's exposure of BMF, was connected to Daim Zainuddin the then finance minister, hence, the government interdicted AWSJ and cancelled the permit of the journalists of that newspaper.

This case was finally brought to the Supreme Court which decided to lift ban forcing the government to propose amendments to the OSA (Means, 1991, p.197; Brown, 2004, p. 126). The amendments were demarcate government documents as confidential and not be disclosed to the public, unless otherwise stated. However, the government's actions to amend OSA caused a demonstration by about 2000 journalists. The National Association of Journalists also gathered 36,000 signatures from the public as a sign of protest to the amendments. To make matters worse, NGOs like the Muslim Youth Movement of Malaysia (ABIM), Aliran Kesedaran Negara (Aliran), Consumers Association of Penang (CAP) and the Bar Council also stepped up protests by organizing dialogues known as the Movement for Freedom and Justice (Brown, 2004, p. 127).

Unfortunately, these protests did not produce any fruitful results as the Parliament went on to pass the amendments in December 1986 by 131 votes against 21 (Brown, 2004, p. 127). Interestingly, in-spite of all these protests, Mahathir's government was successful in dealing with various problems which emerged at every phase of his reign. Then, one wonders what could have been the causes of massive civil disobedience in 1998 ?

It is interesting to note that Mahathir's final phase (1998-2003) was more challenging. This is noted by Mahathir himself in his latest book, entitled A Doctor in the House: The Memoirs of Tun Dr. Mahathir Mohamad, agreed to this. He puts in plain words that 1998 was the most challenging year for him as a Prime Minister because of the economic crisis, the event of Commonwealth Games and also Anwar Ibrahim's sacking as Deputy Prime Minister and the then Finance Minister (Mahathir, 2011, p. 699).

No one denies that Anwar Ibrahim's termination and the succeeding stripping off from him all government positions in 1998 was a major turning point in national politics, even though this expulsion was based on the justification of corruption and sexual misconduct, a claim Anwar felt was a mere political conspiracy coordinated by Dr. Mahathir due to differences between them in dealing with the economic crisis. Anwar was of the view that the economic crisis was mainly due to corruption, cronyism and nepotism, and the only viable recovery according to him was to deal with the International Monetary Fund (IMF), by having high interest rates. On the other hand, Dr. Mahathir placed the blame on outside parties hence he was of the view that the problem required an internal solution as opposed to outside intervention. To make matters worse, Mahathir favoured extending assistance to the weak local companies, something Anwar looked at as a ploy to salvage his cronies (Hilley, 2001).

Therefore, Anwar was dissatisfied with his expulsion from the government so he had to go across the country for 18 days to explain what really happened. Every now and then, in his speeches he had to cite the political ploy to topple him, besides revealing Mahathir administration practices related to corruption, cronyism, nepotism and waste of public money through mega projects and the use of state funds to rescue some of his cronies (Weiss, 2006). Hence, these series of talks acted as the basis for the establishment of a reform movement officially launched on 12 September 1998 in Permatang Pauh, Penang, with main aim to urge his followers to fight for justice, better governance, justice, accountability, policies to benefit the economically weak, freedom and democracy (Weiss, 1999).

Interestingly Anwar's call for reform received an overwhelming welcome from his supporters and communities such as NGOs, opposition parties, student groups, private and public sector workers who were ready to demonstrate civil disobedience through protests. On September 20, before he was arrested, the first mass demonstration led by him was held at the National Mosque and Merdeka Square; a demonstration that mostly 
attracted the support from the community, especially the young people, whose number is estimated to have reached 40,000 people, leading to his arrest on that night. This was the first largest demonstration ever in the history of Malaysian politics, with widespread reports from international media, who were covering the Commonwealth Games at that time in the country (Abbot, 2000; Nair, 2007; Lee, 2010). This massive civil disobedience coincides with the definition by Sheldon (2005) which defines civil disobedience as disobeying or breaking of law for moral, religious, or other reasons, either by an individual or an organized group.

\subsubsection{Abdullah's Era}

Abdullah Badawi took over the leadership of the country in 2003. He had a unique way to regain public support for the Barisan Nasional (BN), which performance dropped in the 1999 general elections. As a result, he was able to bring victory to the $\mathrm{BN}$ in the 2004 general elections. However, in 2007 civil disobedience reappeared and caused BN performance to deteriorate badly in the 2008 general elections. At the second phase of Abdullah Badawi administration, arose a variety of things that revealed the weaknesses in his administration (Zawiyah \& Mohammad Agus, 2013). Therefore people were unhappy and eventually rallied to show their protest. This is consistent with Bedau (1991) who states that civil disobedience are done ".... with the intention of showing frustration by protesting against some laws or policies or decisions of the government (or some of its Officers)."

The civil disobedience began by writing on the Internet. For example, in 2007 there were various blogs, political or otherwise that criticized the leadership of Abdullah Badawi. The authors of these blogs were not only among the common people but they were individuals who had been with the government for a long time. For example, there were blogs by Dr. Mahathir, former Prime Minister of Malaysia, Kadir Jasin, a former chief of the New Straits Times Press (NSTP) and Ahmad Ruhainie a former Member of Parliament (Zawiyah \& Mohammad Agus, 2015).

The government take no actions about the criticism on the Internet and resulted in people returning to the streets to demonstrate. The largest demonstration was by BERSIH group and Hindu Rights Action Force (HINDRAF). BERSIH is a combination of a number of NGOs demanding fair and clean elections. BERSIH rally was held on 10 November 2007. The rally received approximately 30,000 people involving different races demanding a change in the electoral process to be more transparent and fair. Their purpose was to march to Istana Negara to hand over a memorandum to the Yang di-Pertuan Agong (the Agong) on allegations that the Election Commission (EC) was unfair and favour the BN. BERSIH claims include reviewing of the existing electoral rolls, using the permanent ink in the process of voting, the abolition of postal voting and fair media coverage for all political parties. As a result of the rally, police charged 17 people for a rally without a permit (Ooi Kee Beng, 2008; Johan Saravanamuttu, 2008; Gatsiounis, 2008).

Whereas, the HINDRAF demonstration was held on 25 November 2007. HINDRAF purpose was to protest a number of issues including the demolition of Hindu temples by local authorities. Even before the demonstrations, the government has banned the HINDRAF rally, which was held and involved the participation of more than 30,000 people. This led the authorities to take action to disperse the protestors by using tear gas and water cannons. In addition, the police also held roadblocks at major roads which caused so much traffic hold up.

\subsubsection{Najib's Reign}

Najib Razak was appointed as Prime Minister in April 2009. On his appointment he endeavoured to regain the peoples support for Barisan Nasional. This included releasing 13 ISA detainees, including a HINDRAF leader. He also retracted the suspension of publication permit for two opposition main papers, namely Harakah by PAS and Suara Keadilan by PKR (Oon Yeoh, 2009). In addition, in order to regain social support for Barisan Nasional and to differentiate his administration from the previous Prime Minister, Abdullah Badawi, with his popular Islam Hadhari concept, he also introduced his own concept of 1Malaysia with the slogan "1Malaysia: People First, Performance Now. This 1Malaysia concept and slogan is an effort to show that the government is genuinely concerned about the people regardless of race, especially towards the Chinese and Indian communities who had rejected Barisan Nasional in the 2008 General Election (Chin, 2010; Ong Kian Ming, 2011).

During Najib's era, there are ongoing civil disobedience from pro-democracy groups since even the beginning of Najib Razak leadership. These pro-democracy groups comprise of political opposition parties, NGOs and social activists. The active opposition from political parties included PAS, DAP and PKR. The NGOs comprise of Jaringan Rakyat Tertindas (Jerit) (Oppressed People's Network) Malaysian Civil Liberties Movement (MCLM), Suara Rakyat Malaysia (SUARAM) (Voice of the Malaysian People) and Solidariti Anak muda Malaysia (SAMM) Malaysian Young People's Solidarity.

Generally, the pro-democracy groups fight to demand that the government repeal laws regarded as undemocratic 
such as the Internal Security Act (ISA), University and University College Act (UUCA) and Printing Presses and Publication Act (PPPA). Thus they had a Movement to repeal ISA demonstration on 1st August 2009 to demand the government repeal the ISA. In addition, they also demanded that the government review the UUCA and PPPA. This group also objected to the change of leadership in Perak in 2009, and tried to defend the elected state government by holding a protest. The most significant action or event was when this group held the BERSIH 2.0 protest in July 2011 which numbered about 20,000 supporters.

Another protest involved a case of breach of trust by Chairman of National Feedlot Corporation (NFC) who is also the husband of former Minister of Women, Family and Community Development, Sharizat Jalil. The case began with the exposure by a national audit report in October 2010, which showed that corruption, cronyism and nepotism is still rampant in government. Other protests which took place are as follows: in April 2011 against the building of a rare earths plant by Lynas Corporation in Pahang which caused fears of dangerous radioactive effect on the local population; in June 2012 over the listing of Felda in Bursa Saham Kuala Lumpur (Kuala Lumpur Stock Exchange); in April 2012 by students at Dataran Merdeka who demanded that the government abolish the National Higher Education Fund Corporation (PTPTN); and in November 2012 against the installation of Automated Enforcement System (AES) to detect traffic violations on roads because it would burden the people. Civil disobedience continues after the 2013 general election. For example, protest against the result of the 2013 general election, protest against mismanagement of IMDB funds and protest by BERSIH Group which is BERSIH 4.

\section{Conclusion}

Civil disobedience entails actions taken by certain groups against the government or its officers. This is because there is a policy or specific legislation that is considered unfair to the public. For example Official Secret Acts, Internal Security Acts, University and University College Act and Printing Presses and Publication Act. In Malaysia, civil disobedience is carried out by pro-democracy groups to demand changes in the government pertaining to the issues related to political and administrative matters. The method used to protest is through street demonstrations. The most powerful civil disobedience occurred in 1998 due to the sacking of Anwar Ibrahim. While at the time of Abdullah Badawi and Najib Razak, civil disobedience occurred due to electoral, economic and democratic issues.

\section{Acknowledgements}

I would like to acknowledge the valuable contributions of the following persons; Prof. Dato' Wira Dr. Mohamed Mustafa Ishak Vice Chancellor, Universiti Utara Malaysia (UUM), Prof. Dr. Noor Azizi Ismail Deputy Vice Chancellor (Research and Innovation), UUM, All the staff of the department of Research and Innovation Management Centre, UUM and last but not least The Ministry of Higher Education, Malaysia for awarding us with the FRGS Grant to carry out this research project.

I also would like to thank the researcher for this project; Prof. Dr. Kamaruddin Ngah, Assoc. Prof. Dr. Mohammad Agus Yusoff, Assoc. Prof. Dr. Zaheruddin Othman, Dr. Mohd Fitri Abdul Rahman, Dr. Mohd Na'iem Ajis, and Madam Zalinah Ahmad.

\section{References}

Abbot, J. P. (2000). Bittersweet victory: the 1999 Malaysian general election and the Anwar Ibrahim affair. Round Table, 354(1), 245-258. https://doi/abs/10.1080/750459438

Bedau, H. A. (1991). Civil disobedience and personal responsibility for injustice. In H. A. Bedau (Ed.), Civil disobedience in focus (pp. 49-67). London: Routledge.

Brown, G. K. (2004). Civil society and social movements in an ethnically divided society: the case of Malaysia, 1981-2001. (Unpublished doctoral dissertation). University of Nottingham, England.

Chin, J. (2010). Malaysia: the rise of Najib 1Malaysia. Southeast Asian Affairs, 165-179. Retrieved from https://muse.jhu.edu/article/429574/pdf

Gatsiounis, I. (2008). Beyond the veneer: Malaysia's struggle for the dignity and direction. Singapore: Monsoon.

Hilley, J. (2001). Malaysia: Mahathirisme, hegemony and the new opposition. New York: Zed Books.

Johan Saravanamuttu. (2008). A tectonic shift in Malaysian politics. In Ooi, Kee Beng, Johan Saravanamuttu \& Lee, Hock Guan (Eds.), March 8: eclipsing May 13 (pp. 33-79). Singapore: Institute of Southeast Asian Studies.

Klang, M. (2005). Virtual sit-ins, civil disobedience and cyber-terrorism. In M. Klang \& A. Murray (Eds.), 
Human rights in the digital age (pp.135-145). London: Glasshouse Press.

Lee, J. C. H. (2010). Islamization and activism in Malaysia. Petaling Jaya: Strategic Information and Research Development Centre.

Mahathir Mohamad (2011). A doctor in the house: the memoirs of Tun Dr. Mahathir Mohamad. Petaling Jaya: MPH Group Publishing.

Means, G. P. (1991). Malaysian politics: the second generation. Singapore: Oxford University Press.

Nair, S. (2007). The limits of protest and prospects for political reform in Malaysia. Critical Asian Studies 39(3), 339-368. http://dx.doi.org/10.1080/14672710701527345

Ong, K. M. (2011). Malaysia in 2010: resurgent Najib and BN, stumbling Anwar and PR. Southeast Asian Affairs, 132-157. Retrieved from http://www.jstor.org/stable/41418641

Ooi, K. B. (2008) Lost in transition: Malaysia under Abdullah. Petaling Jaya: Strategic Information and Research Development Centre.

Oon, Y. (2009). Najib's first 100 days. Petaling Jaya: Gerak Budaya Enterprise.

Quigley, C. N., \& Bahmueller, C. F. (2001). Civitas: a framework for civic education. Center for Civic Education: Calabasas, CA.

Rawls, J. (1971). A theory of justice. Massachusetts: Belknap Press.

Sheldon, G. W. (2005). The encyclopaedia of political thought. New Delhi: Viva Books.

Smith, W. (2004). Democracy, deliberation and disobedience. Res Publica, 10(4), 353-377. http//doi:10.1007/s11158-004-2327-5

Weiss, M. L. (1999). What will become reformasi? Ethnicity and changing political norms in Malaysia. Contemporary Southeast Asia, 21(3), 424-427.

Weiss, M. L. (2006). Protest and possibilities: civil society and coalitions for political change in Malaysia. Stanford: Stanford University Press.

Zawiyah Mohd Zain \& Mohammad Agus Yusoff. (2013). Civil disobedience and its impact on 2008 general election. Contemporary Social Sciences, 22(3\&4), 91-105.

Zawiyah Mohd Zain \& Mohammad Agus Yusoff. (2015). The emergence of civil disobedience: comparison during Dr. Mahathir and Abdullah Badawi era. Mediterranean Journal of Social Sciences, 6(1), 279-285. http:/doi:10.5901/mjss.2015.v6n1s1p279

\section{Copyrights}

Copyright for this article is retained by the author(s), with first publication rights granted to the journal.

This is an open-access article distributed under the terms and conditions of the Creative Commons Attribution license (http://creativecommons.org/licenses/by/4.0/). 